\title{
Germans divert spent fuel to Dounreay
}

London. A German research institute last week signed an agreement with the Dounreay reprocessing plant in Scotland under which Dounreay will accept fuel elements from its research reactor containing bomb-grade highly enriched uranium (HEU). Under the terms of the Nuclear Non-Proliferation Treaty, these should have been shipped to the United States.

The Hahn Meitner Institute (HMI) in Berlin says it was forced to take the decision because the United States had delayed so long in fulfilling its commitments to take the fuel, and its own storage facilities had become dangerously overloaded.

But the signing of the contract with Dounreay came only one day after a US court of appeals lifted an injunction on the import of HMI's fuel elements.

The Nuclear Control Institute, an independent watchdog group, holds the US Department of Energy (DoE) responsible for forcing Germany to strike a deal with Dounreay, which contravenes international agreements aimed at eliminating civilian trade in bomb-grade uranium.

In 1978, the United States agreed, as part of the 1978 Reduced Enrichment for Research and Test Reactors (RERTR) agreement, to take back spent fuel rods of US origin from foreign research reactors that were prepared to convert from the use of bomb-grade HEU to the less efficient low-enriched uranium (LEU). Most reactors agreed to do this.

But protests from antinuclear pressure groups in the late 1980 s caused the United States to renege on its promise to take back the spent fuel. Then, in 1993, the Clinton administration renewed the US commitment to anti-proliferation and called for a full environmental impact statement on the consequences of accepting spent fuel, which is due to be published in December.

In the meantime a backlog of 24,000 spent fuel rods in non-US research reactors built up. Last summer the DoE agreed to accept some of these rods from eight European facilities that had acute storage problems. But the landing of the first shipment of 153 rods was held up when the state of South Carolina argued that the full environmental impact statement should be awaited before any import could be allowed (see Nature 373, 547; 1995). After weeks of court battles, the import was finally accepted last September and taken into storage at the South Carolina Savannah River Site.

A remaining injunction on a second shipment of 157 fuel rods, including the shipment of 52 from the HMI, was lifted at the end of June. But because the lifting was subject to the appeal court's final opinion, which was delivered only last week, the DoE chose not to risk allowing import in case further injunctions left bomb-grade uranium once again unprotected on the high seas.

The delay angered the NCI, which calls it a "highly irresponsible" act by energy

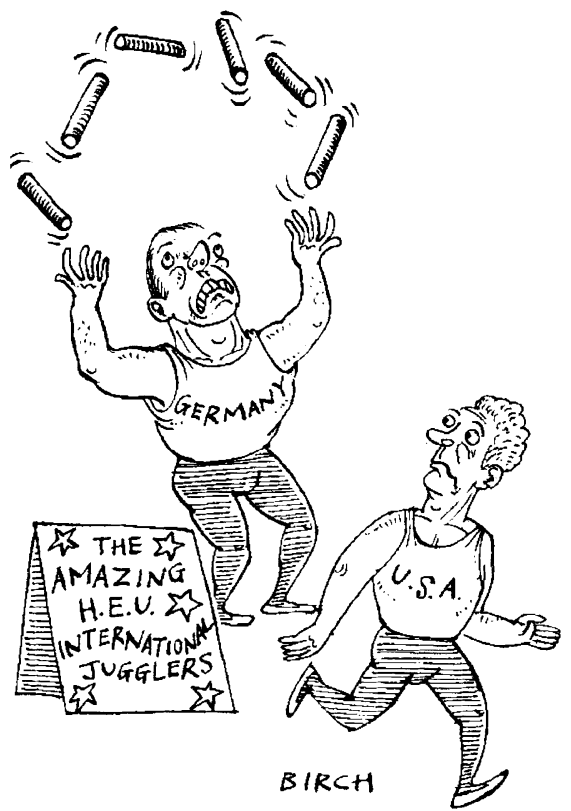

secretary Hazel O'Leary, bearing in mind the urgency of the case. "It put the RERTR in danger", says an NCI spokesman, Alan Kuperman, "and it makes us worry about the US commitment to take back all 24,000 fuel elements, if we can't muster the courage to import 150."

The HMI says that it could no longer wait for an import licence, which it has still not received, despite statements from the DoE that it is now prepared to authorize shipment, because the court's final judgement came down very strongly in its favour.

"We have always stressed to Washington that we need to get rid of our waste by the end of September", says Bernd Jahn, administrative director of HMI, "so our decision [to go to Dounreay] should not come as a surprise."

But the DoE is apparently still hoping that the HMI will change its mind and send its fuel to Savannah River. This will not happen, says Jahn.

Jahn says that once the immediate pressure on the HMI's storage is relieved, then the institute will consider at leisure all the options for handling waste in the future. This will include discussions with reprocessing plants in Europe. Experience has taught him, he says, not to rely exclusively on a single US option because the strength of local opposition there makes it an unpredictable partner.

The research reactor at the HMI, which provides neutrons for the study of materials, will, however, continue its plans to convert to the use of LEU in the future.

Alison Abbott

\section{Tokyo students organize Internet protest}

Tokyo. Three graduate students at Tokyo University who set up a home page on the World Wide Web to register protests against France's plans to resume nuclear tests in the Pacific (Nature 376, 376; 1995) have had to switch to a commercial Internet site to cope with the deluge of responses.

More than 55,000 people from over 100 countries have recorded their protests on the home page set up on the university computer system last month by Seishi Shimizu and Yuichi Nishihara of the physics department and Kiroh Harada of the engineering faculty.

The home page, which was put on a university server intended primarily for research into elementary particle physics, was getting overloaded with responses, says Nishihara, and this could have limited the number of signatures they could collect.

The three decided instead to move the page to a commercial server run by the company Internet Initiative Japan. "We are paying for the site out of our own pocket money", says Nishihara, "with money saved by drinking less beer." The students also decided to move the page because they felt it inappropriate to continue using a university server for the protest.

They stopped collecting names on 15 August, the fiftieth anniversary of the end of the Pacific war, by which time the tally had reached 55,769. They are now adding the names of thousands more who signed a chain e-mail letter which two of the students began earlier in the summer but which had to be stopped when their mailboxes became swamped. The final list of protesters will be presented to the French embassy in Tokyo this week.

Nishihara says that they will not continue this activity much longer because they have to work on their MSc theses. But they hope that they will have inspired others to start their own petitions. The page with the text of the protest translated into more than 20 different languages will remain on the server until at least the end of September and can be accessed at http://www.iijnet.or.jp/nuke/.

David Swinbanks 